\title{
Research On the Optimization Design of Campus Environment of Northwest A\&F University Under the Stormwater Management
}

\author{
Liyan Gong ${ }^{1, a}$, Ning Cao ${ }^{1, b, *}$ \\ ${ }^{1}$ School of Landscape Architecture and Arts, Northwest A\&F University, Taicheng Road, Yangling, China \\ a liyangong@nwafu.edu.cn, b Cning@nwafu.edu.cn \\ *corresponding author
}

Keywords: Landscape Architecture, Stormwater Management, Campus Landscape

\begin{abstract}
College campus is an important part of urban construction. With the rise of sponge city construction, college campus can be used as the carrier of storm water management scheme. Based on the theory of storm water management, campus has functions like learning and communication, at the same time the campus environment can be used as the carrier of runoff absorption, play its potential ecological benefits, relieve the pressure of urban drainage, and add new creativity to the sustainable development of the city.
\end{abstract}

\section{Introduction}

College campus is an important part of urban construction. With the rise of sponge city construction, college campus can be used as the carrier of storm water management scheme. There have been many successful cases of campus landscape planning and design based on Storm Water's management system abroad. For example, Marsh Hall of Salem State University, Shoemaker Green of University of Pennsylvania, Thailand Siree Ruckhachat Nature Learning Park. Based on the theory of storm water management, campus has functions like learning and communication, at the same time the campus environment can be used as the carrier of runoff absorption, play its potential ecological benefits, relieve the pressure of urban drainage, and add new creativity to the sustainable development of the city.

\section{The System of Stormwater Management}

Integrated water management(IWM) is a holistic approach to the water cycle. An integrated water management approach considers a broad range of water sources that may be suitable for different types of demands or end needs and involves developing an understanding of an appropriate water hierarchy that is required to service these future demands. In 1970s, the United States first put forward the Best Management Practices(BMPs), and then put forward the best management measures for controlling rainfall runoff and water quality, managing rainwater discharge and sewage overflow. In 1990, Maryland introduced low impact development (LID) on the basis of BMPs. As a supplement to BMPs, it is a sustainable integrated rain flood management strategy, which combines various runoff control techniques through reasonable site development mode, and restore the site to its natural hydrological state before development. In the late 1990s, Australia proposed the water sensitive urban design (WSUD). In 2012, China put forward the Sponge City Theories which mean cities like sponges, have good 'elasticity' in adapting to environmental changes and responding to natural disasters, such as absorbing, storing, seeping and purifying water when it rains. Releasing the stored water and use it when necessary.

\section{Situation Analysis}

Northwest A\&F University is located in Yang Ling demonstration area of Shaanxi Province. It is a semi-humid and semi-arid climate area in warm temperate zone of East Asia. It is characterized 
by warm and windy spring, hot and rainy summer, cool and continuous rain in autumn, cold and dry winter. The annual precipitation is $635.1-663.9 \mathrm{~mm}$, the average temperature is $12.9^{\circ} \mathrm{C}$. The campus area is $3.769 \mathrm{~km}^{2}$, the building area is $1.2806 \mathrm{~km}^{2}$.

\subsection{Broken Water System}

The water system in the campus is broken and not closely connected. The Artificial Lake of Cultural and Ecological Park and the West Lake (Figure 1) are two main water bodies, located in the east and west of the campus respectively. Both are man-made landscape pools, which are openair surface water. The self-purification ability is low and easy to be polluted. With the expansion of the campus, the hard surfacing area in the campus gradually becomes larger, which makes the landscape water system exist independently and are not connected with each other.

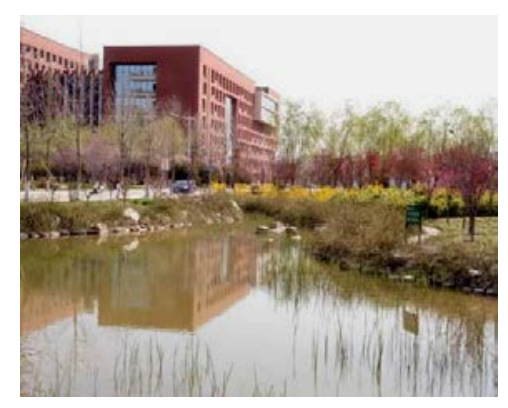

Figure 1 The West Lake.

\subsection{The Poor Regulation Ability of Stormwater}

On campus, there are many rigid pavements which are not conducive to rainwater infiltration. In addition, many green spaces on campus are raised hills or flat ground such as Chinaberry Square and Economic Arboretum where are higher than roads, are not sunken green space, is not conducive to the rainwater collection, can not play the role of stagnant water, thus cannot alleviate the problem of surface water accumulation. There is heat island effect in summer and waterlogging in rainy season-September and October.

\section{Design Approach}

\subsection{Bioretention Facilities}

There are many kinds of bioretention facilities such as green roof, rain garden, sunken green space, ecological tree pool, bioswale.

Campus is located in warm temperate are and semi-humid semi-arid climate zone, suitable for the construction of sunken green space. Designing sunken green space in areas with high vegetation coverage and low terrain such as Cultural Ecological Park, the south side green space of Expert Apartment and so on. The overflow outlet set in the middle of the green space or at the junction with the hardened ground. In order to enrich the sunken green landscape, these space can display sculpture, rockery and other landscape installation.The sunken green space can improve the microclimate of the campus, make the air circulation and water exchange, adjust the air temperature, humidity and alleviate the "heat island effect", bring cool in summer and relieve the drainage pressure in the rainy season.

The ecological tree pool (Figure 2) is generally composed of planting soil, sand filter, drainage system and trees. It covers a small area and it can accumulate, infiltrate and purify the peripheral runoff. The design of ecological tree pool can be used in the parking lot in front of No.3 teaching building and in the west side of the library. Ecological tree pool and road gully joint design can improve the traditional road gully sewage purification effect. 


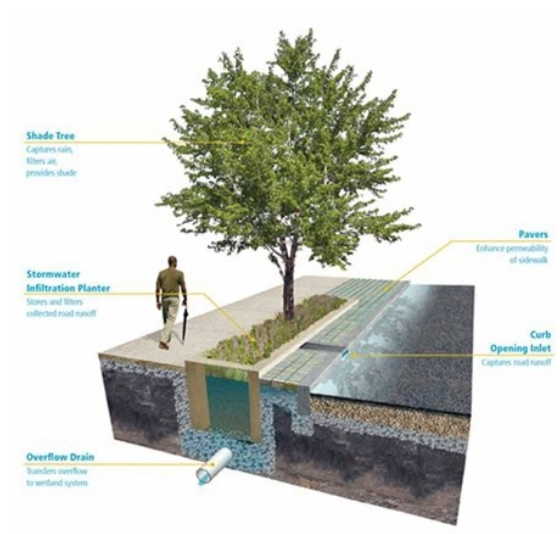

Figure 2 The Operational Principle of Ecological Tree Pool.

\subsection{Porous Paving}

At present, in addition to the Beech Square uses porous paving, many other sites use rigid pavements. Setting the permeability pavement with porosity of $15 \%$ to $25 \%$ in the hard pavement area can reach $31-52 \mathrm{~L} /(\mathrm{m} \cdot \mathrm{h})$ and guarantee the effect of unblocked water permeability.Setting porous asphalt concrete pavement on Cherry Avenue, Ginkgo Boulevard and so on, setting the porous bricks, grass planting brick or stone pavement on secondary roads. When heavy rain season or short period of heavy rainfall, rainwater permeates through porous paving, alleviate drainage system pressure effectively, slow down runoff curve, reduce peak value, make the flow rate rise and drop slowly. At the same time, it can alleviate the ponding and waterlogging on the road, ensure the safety of road traffic and pedestrians, and prevent the contradictory situation - when it rains, there is a flood and when it no rain, there is a drought. When it rains, the porous pavement infiltrates on the spot, conserves the lower layer of soil, supplements the groundwater, and the overflow rainwater can flow into the surrounding sunken green space to replenish the plant water, so that the soil below the road that was originally closed will be restored to life and become the road sponge on campus.

\subsection{Planting}

Vegetation can effectively control storm water. Vegetation can not only absorb storm water kinetic energy, control soil erosion, maintain absorption ability, but also decrease runoff velocity and rainwater discharge rate. Local plants with strong roots and strong resistance are planted to form a stable local plant ecosystem in order to absorb and purify runoff. For instance, the iris, calamus, and lotus of the perennial ground cover; the flower of williams elder, sabina vulgaris, holly, and alchornea davidii of the shrubs; and the chinaberry, red maple, and paper mulberry of the arbor. Planting local plant reduces the cost of plant landscape maintenance, builds good plant landscape effect, and ensures the ability of the plant to manage the quantity and quality of rainwater.

\section{Conclusion}

Rainwater treatment apply to campus landscape, not only express the artistic landscape, but also realize the pursuit of landscape ecological function. As a famous agricultural and forestry university, the Northwest A\&F University has been actively promoting the ecological campus construction, which combines stormwater management concept with the campus planning and design. Through the specific landscape design approaches, the ecological function of water system can be brought into play, and the construction of micro-scale sponge system can be realized, the campus landscape and ecological environment can be promoted, and the scientific values of sustainable development can be displayed. And It is also a way to provide a reference to other universities' landscape design. 


\section{References}

[1] YU Kongjian. The Philosophy of 'Sponge City'. Landscape Architecture Frontiers. Vol. 14(2015) No. 2, p. 4-9.

[2] YU Kongjian. Three Strategies for Sponge City: Absorption, Deceleration and Adaptation.South Architecture. (2015) No. 3, p. 4-7.

[3] YU Kongjian, LI Dihua, YUAN Hong, et al. Sponge City: Theories and Practices. City Planning Review. Vol.39(2015)No.6, p. 26-36.

[4] GONG Liyan, SHANG Yanyun, A brief Analysis on the Reconstruction of Urban waste Space-Taking the waste garbage dump as an example to transform into a City Park. Urban construction theory research.(2014)N0.10, p. 2

[5] PANG Wei. Sponge City: Theories and Practices. Liaoning Technology Press,2017, p.10-15. 